\title{
Standardized Arabic as a Post-Nahda Common Ground: Mattai bar Paulus and His Use of Syriac, Arabic, and Garshuni
}

\author{
T.C. Baarda
}

The need to have a common ground is most obvious where members of a minority community must access the arenas defined by members of a majority community. But common grounds are present in all situations in which different communities meet, and even in intra-communal situations it can be necessary to negotiate common means of communication. In this paper, I look at a case in which members of different branches of Syriac Christianity in mandatory Iraq communicated with each other; I examine the ways they used the Arabic and Syriac languages, and how this varied according to the functions of their language and their audiences.

While Arabic is by far the most dominant language in the Middle East, the linguistic environment in the region is not straightforward at all and has never been. Diglossia is a well-known phenomenon, as is the existence of minority languages for both Muslim and non-Muslim communities. ${ }^{1}$ What makes the situation even more complicated is the fact that most minority Christian communities have a liturgical language that is normally not used outside church contexts, but that does play a significant role in the expression of the community's identity.

This linguistic complexity is certainly the case for Syriac Christians, the group of Christians central to this paper. The Syriac Christians formed a significant minority in Mandate Iraq, especially in the northern part. Apart from Neo-Aramaic, which is a group of dialects spoken and written by members of the community until today, they used the liturgical language of Classical Syriac.

One particular case is central to this paper: the letters from the Syriac Orthodox deacon Mattai bar Paulus of Mosul, to Alphonse Mingana, who was originally a Chaldean from a village close to the city of Zakho (modern northern Iraq) and who later became known as an Orientalist in Britain. Mattai, a dea-

1 For an introduction to the phenomenon of diglossia, see Kees Versteegh, The Arabic Language (Edinburgh: Edinburgh University Press, 2001), 189-208. 
con, worked as a scribe for his church and produced numerous manuscripts. Mingana, as an Orientalist, was his customer and a personal friend. The men were from different branches of Syriac Christianity. A large number of letters from Mattai to Mingana have been preserved and are available in the Special Collections of the Cadbury Research Library in Birmingham, England. Combined with a biography that was made about Mattai by the Syriac Orthodox author Nematallah Denno, we can make interesting assertions about the various choices Mattai made when communicating with Mingana and in his other writings.

In Mattai's writings and his biography, he uses Arabic the most, rather than Syriac or Neo-Aramaic. This is not very surprising. For many centuries Arabic had had an important position with the Syriac Orthodox Christians, especially as a written language, and in certain places it had even replaced Aramaic as the spoken vernacular. ${ }^{2}$ But Arabic had never replaced Syriac and Aramaic completely: it has always had a position alongside Syriac and Neo-Aramaic, and it is this position that interests me most: what made an author decide to favor Arabic over their "own" communal Syriac or Aramaic? And from another perspective: to what extent did the author's use of Arabic correspond to the use of Arabic in the Muslim environment?

Using Arabic was a choice that in itself makes perfect sense from the perspective of Mattai bar Paulus, as a Syriac Orthodox Christian in Mosul he used the language that he would normally use. But the documents do not show the usage of Arabic alone. In specific places Classical Syriac is used as well, and even more important, we see the use of Garshuni, which is the practice of writing Arabic in the Syriac alphabet. The mix of different languages and scripts presents us with an ideal case to assess to what extent Christians, who had Arabic at their disposal but who also had their own communal language, communicated on common grounds with their Muslim neighbors and their fellow Christians from other denominations. The way Mattai and Nematallah use Arabic is just as interesting. A considerable number of scholars have pointed out that the nahda, the literary revival of the Arabic language that began in the nineteenth century, is related to the linguistic integration of Christians into the rest of the Arab world. Evidence for this is, however, mainly restricted to Lebanon and Syria. Is this phenomenon, which in this article I refer to as the nahda hypothesis, also true for the texts we consider here?

2 John Joseph, Muslim-Christian Relations and Inter-Christian Rivalries in the Middle East: The Case of the Jacobites in an Age of Transition (Albany: State University of New York Press, 1983), 22. 
Even though the current case of an early twentieth-century Syriac Orthodox scribe in Mosul cannot be taken as representative of all Christian communities in the Middle East, my aim in this article is not only to highlight the case of Mattai bar Paulus, but also to show that Mattai's case can serve as an example by which we can study the process in which Christians in the Middle East used Arabic and other languages during the nineteenth and twentieth century to create a common means of communication.

After an introduction to the material, I briefly discuss the documents that form the basis of this paper. I follow this with a comparison to developments in Iraqi church inscriptions, where features in the material call for a discussion of the notions of Middle Arabic, Modern Standard Arabic, and the significance of Garshuni; I address these in a separate section. In the last part of the article I discuss the common grounds between Muslims and Christians on the one hand, and among Christians from different denominations on the other. As I argue, Mattai appears to be in a different position than that of other contemporary Syriac Christians.

\section{Twentieth-Century Manuscript Production: The Scribe Mattai bar Paulus and His Letters to Mingana}

Mattai had always been based in Mosul, the most important city of northern Mesopotamia that was incorporated, during the years after World War I, into the new state of Iraq. Northern Mesopotamia, known for having a majority of Kurdish inhabitants, is in fact a place of great religious and ethnic variety. Harry Charles Luke, who worked for the British Colonial Office at the time of the British mandate in Iraq, shows that the British had also seen this when they entered Mesopotamia: "There are few parts of the world (outside the Caucasus, than which there is no more intricate mosaic of races) so baffling to the ethnographic mapmaker as the district which was once known as the Vilayet of Mosul." ${ }^{3}$ While the vast majority of the population was Muslim, both Kurdish and Arab, all branches of Syriac Christianity were present in Mosul and the surroundings.

Compared to cities like Beirut and Damascus, Mosul was a relatively peripheral city in the Ottoman Arab world, at least with regard to its intellectual activity. Pierre-Jean Luizard noted that in the latest phase of Ottoman history, Mesopotamia, and especially Mosul, lagged behind in comparison to other

3 Harry Charles Luke, Mosul and its Minorities (London: Hopkinson, 1925), 13. 
places in the Arab world; he wrote that the intellectual elite had yet to rise, though it had already developed in the Levant and in Egypt. ${ }^{4}$ While Mosul was an important regional center, as well as an important place of Syriac Christianity, it was not central to the new intellectual developments spreading across the rest of the Arab world.

It was in Mosul that Mattai bar Paulus ${ }^{5}$ (1861-1947) was active. He was a deacon (shammās in Arabic and mshamshōnō in Syriac) of the Syriac Orthodox Church, and in this function he worked as a scribe. We do not know much about him. We know him mainly through Alphonse Mingana, to whom Mattai delivered a large quantity of manuscripts. A considerable number of these were produced by Mattai on Mingana's request. Mingana mentions Mattai a few times in his publications, most notably in his catalogue of the Syriac manuscripts in his own collection. ${ }^{6}$ In 1959, the Dominican scholar J.M. Fiey, who stayed in Mosul for a long time, mentions him first in his description of the city's Christian buildings. He calls him a "copiste jacobite fameux" (famous Jacobite copyist) and mentions that he met with him in person. ${ }^{7}$ Later, in 1967, Fiey writes, in the context of a manuscript that Mingana used in one of his works, that Mattai was a deacon whose full name was "Matti b. Paulos, b. Na'mat-Allah, b. 'Awdicho', b. Potros" and that he used to work for Mingana. It is especially interesting that he mentions that Mattai did not know any foreign language. ${ }^{8}$

Mattai is mentioned in the The Scattered Pearls: A History of Syriac Literature and Sciences by the late Syriac Orthodox patriarch Ignatius Afram I Bar-

4 Pierre-Jean Luizard, La formation de l'Irak contemporain:le rôle politique des ulémas chiites à la fin de la domination ottomane et au moment de la construction de l'Etat irakien (Paris: Editions du Centre national de la recherche scientifique, 1991), 81 and 84 .

5 Mattai's name has an abundance of forms, and Mattai himself did not use the same form consistently. We will see some of the names that he used himself later on. In western scholarly literature he is most commonly known as Matti/Mattai bar Paulus and Matthew, son of Paul.

6 A. Mingana, Catalogue of the Mingana Collection of Manuscripts, now in the Possession of the Trustees of the Woodbroke Settlement, Selly Oak, Birmingham, part I: Syriac and Garshüni manuscripts (Cambridge: Heffer, 1933).

7 J.M. Fiey, Mossoul Chrétienne: Essai sur l'histoire, l'archéologie et l'état actuel des monuments chrétiens de la ville de Mossoul (Beirut: Imprimerie catholique, 1959), 30. Fiey, a well-known Catholic priest and scholar, wrote this description after a stay of twenty years in Iraq. While the book was meant to describe the Christian monuments of Mosul, it also gives interesting information about the situation of the Christians during his visit (1939-1959).

8 J.M. Fiey, "Auteur et date de la chronique d' arbèles," L'orient syrien, revue trimestrielle d'Etudes et de Recherches sur les Eglises de langue syriaque, publiée avec la collaboration du Centre National de la Recherche Scientifique 12 (1967): 269. 
soum, who writes that "[d]eacon Matthew Paul transcribed more than forty volumes of different subjects, including commentaries on the Pentateuch, theology, ecclesiastical jurisprudence, history, literature and asceticism. They are preserved in different libraries. He is still living and has passed his eighty-sixth year of age." ${ }^{\prime 9} \mathrm{He}$ is also mentioned in a chapter on Syriac scribes, at the end of a long list. Mattai is the only deacon in the list, the others held higher ranks in the ecclesiastical hierarchy, and he is the only one of whom Barsoum writes more than just his name and year. J.F. Coakley writes that the number of manuscripts that Barsoum ascribes to him, forty, is too low..$^{10}$

As stated, Mattai belonged to the Syriac Orthodox Church, while Mingana was originally a Chaldean. Both are Syriac churches which, together with the Syriac Catholic Church and the Church of the East, use Classical Syriac as their liturgical language. Without going into the historical or theological details, it is important to mention that the Syriac Orthodox Church belongs to the western branch of Syriac Christianity, and the Chaldean Church belongs to the eastern branch. This difference is significant in relation to the Syriac language, which is written in three different but similar scripts. The oldest of the three, estrangelo, is used by both branches, but the younger two are specific to the church: West Syriac Christianity has a script called serțō, and the eastern branch has a script that is called madhnhoyō, which simply translates to "eastern"- therefore it is usually referred to as East Syriac script. The use of the scripts therefore reveals to which community the writer belongs, even if the text would otherwise not reveal it. ${ }^{11}$ Besides a difference in script, there is also a difference in the tradition of pronunciation, but because this is not terribly relevant in relation to written material, I do not go deeper into that. ${ }^{12}$

9 Ignatius Aphram I Barsoum, The Scattered Pearls: A History of Syriac Literature and Sciences, trans. and ed. Matti Moosa (Piscataway, NJ: Gorgias Press, 2003), 22. There is a translation of Ighnāțiyūs Afrām Barṣawm, Al-lu’lu’al-manthūr fìtārīkh al-'ulūm wa-l-ādāb al-suryāniyya (Aleppo, 1956) which I did not have access to.

J.F. Coakley, "A Catalogue of the Syriac Manuscripts in the John Rylands Library," Bulletin of the John Rylands Library 75 (1993), 113. Coakley must be right, as there are already fifty manuscripts in the Mingana collection (see below).

11 This is, for instance, apparent in modern-day Ankawa, a Christian city close to the Iraqi Kurdish capital of Erbil, where many signs on the street have three languages: Kurdish, Arabic, and Aramaic. The Aramaic is printed in East Syriac script. Though upon inquiry people say that none of the Syriac branches is favored, the script reveals that the Eastern branch is dominant.

12 It is, however, important for the transcription of Syriac words. In this paper, the West Syriac pronunciation has been followed consistently in transcriptions, which is characterized by the use of the long $\bar{o}$ for the East Syriac long $\bar{a}$ and for the merging of $b$ and $v$ in $b$ as well as $p$ and $f$ in $f$. 
There are many links between Mattai and Alphonse Mingana (c. 1870-1937). Mingana was originally a Chaldean Christian who lived close to Zakho in modern Iraq, but in 1913 he broke with his church and moved to Britain..$^{13}$ In Britain he became known as an Orientalist with an extensive collection of manuscripts that he collected during his travels to the Middle East and from manuscript sellers in Europe and the Middle East. Mattai was thus one of the people who provided Mingana with manuscripts.

In his Catalogue, Mingana was normally not very informative about the provenance of the manuscripts that were part of his collection, but he gave information about the age of the manuscripts and the copyists, usually by providing a summary of the colophon. Mattai always made himself known in his colophons, and thus we know that he produced about fifty of the manuscripts in this collection - part of these were simply bought by Mingana, but a considerable number were copied especially by Mattai for Mingana's collection; Mingana acknowledged this in various places in his Catalogue. ${ }^{14}$ This is probably what Fiey meant when he writes that Mattai worked for Mingana (see above). A few manuscripts copied by Mattai are further to be found in the John Rylands Library in Manchester (United Kingdom); these were brought there by Mingana. The Syriac manuscripts in Manchester were cataloged by J.F. Coakley, who identifies twenty-five manuscripts of this collection as acquisitions by Mingana. Four of these were copied by Mattai, but none on Mingana's request. ${ }^{15}$

13 The sources concerning this dispute are obscure and partly contradict each other, but for our present purpose it is interesting that Christiaan Snouck Hurgronje mentions, in correspondence with Theodor Nöldeke in 1925 many years after his move to Britain in 1913, that the Catholics did not want to be in contact with him anymore. C. Snouck Hurgronje, Abdoel-Ghaffaar: Sources for the History of Islamic Studies in the Western World, vol. 1: Orientalism and Islam: The Letters of C. Snouck Hurgronje to Th. Nöldeke from the Tübingen University Library, published by P.Sj. van Koningsveld (Leiden: Documentatiebureau Islam-Christendom, Faculteit der Godgeleerdheid, 1985), 335. There is an indication that Mingana had developed positive feelings toward the Syriac Orthodox Church: right after his election, he writes about their patriarch Ignatius Afram I Barsoum, that he is the "highest ecclesiastical dignity found in this world." Cadbury Research Library, DA66/1/3/5 ("Correspondence concerning the Church of Malabar"), letter from Mingana to Barsoum, dated 3 January 1933. The letter was written in English instead of Arabic or Syriac because at that time Mingana was not able to use his right hand, while for English a typewriter could be used. Another letter, dated 8 December 1932, expresses his fear that "a great number of the members of the Syrian Church of India will join the Church of Rome." See for instance Mingana, Catalogue, 1:429.

15 Coakley, "A Catalogue," 112-113. 
Mingana is not the only manuscript collector who commissioned or purchased Mattai's manuscripts. Coakley's catalog reveals that part of the Syriac manuscripts in the John Rylands Library, the manuscripts of Mingana's patron James Rendel Harris, were sold to Harvard University in $1905 .{ }^{16}$ A quick search in the digital catalog of the Harvard libraries shows that some of these manuscripts were copied by Mattai, long before Mingana went to Britain. ${ }^{17}$

Mattai cannot be found listed in the indices of four important manuscript catalogs that describe Syriac manuscripts in various ecclesiastical libraries in and close to Mosul. The catalogs describe libraries from different denominations, including the Syriac Orthodox. ${ }^{18}$

Mingana's personal archive in the Cadbury Research Library in Birmingham contains a vast amount of personal correspondence in English, French, and German, mainly with other scholars around Europe and the United States. ${ }^{19}$ One folder of the Mingana papers contains a good number of documents in Arabic and Syriac, and except a number of letters from the Syriac Orthodox patriarch Barsoum (written in Syriac) most of the documents are letters from Mattai bar Paulus. Only the letters from Mattai to Mingana are preservedfrom the letters that went to the other direction nothing is available. ${ }^{20}$ All the letters are in Arabic and in Arabic script.

In this article, I consider the material in two parts. First, there is the large amount of correspondence between Mattai bar Paulus and Alphonse Mingana.

\section{Ibid., 107.}

17 Many thanks to Dr. Jan van Ginkel (Leiden University), who mentioned the existence of Mattai's manuscripts among Rendel Harris' manuscripts. He also pointed out that documents on Mattai might also be present in the Rendel Harris' correspondence, of which at least part is available in the Special Collections of the John Rylands Library.

18 Fahāris al-makhțūțāt al-suryāniyya fì l-Irāq, part one, Maktabāt al-Mawșil wa-ațrāihìā, and part two, Makhțūtāt 'Aqra, dayr mār Mattā, Duhūk, kanīsat mār Kūrkīs fì Barțalla, mutrāniyya al-suryān al-urthūduks fi l-Mawșil (Baghdad: Maṭba'a al-Majma' al-'Tlmī l'Irāqī, 1977-1981). The indices of these volumes, which were prepared by the Iraqi scholar Benjamin Haddad, include an index of scribes. The other two catalogs are Bihnām Dāniyāl, Fahāris al-makhțūtāt al-suryāniyya fì Barțalla (Duhok: Dār al-Mashriq al-Thaqāiiyya, 2013) and Bihnām Sūnī, Fahāris makhțūțāt bīat wālidat Allāh Maryam —al-țāhirafìBaghdēdāQaraqōsh (Duhok: Dār al-Mashriq al-Thaqāfiyya, 2010), both kindly provided by Father Shlīmūn Îshō Khōshābā at Dār al-Mashriq in Duhok, Iraq.

19 The fonds is called Papers of Alphonse Mingana, carrying finding number DA66. Its comprehensive inventory can be found in the library's excellent online catalog.

This is probably because Mingana wrote to Mattai in Arabic or Syriac script, so that it was not possible to produce carbon copies of the letters, as he (or his secretary) did with letters that he wrote in European languages. 
Second, the Mingana papers contain a document written by the prominent Syriac Orthodox writer Nematallah Denno.

\section{Mattai's Letters to Mingana}

Almost a hundred letters from Mattai to Mingana are present in the Mingana papers. They are dated from 1926 to 1935, a year after Mingana's second journey to the Middle East (both the first and the second journey brought him to Mosul), and up until two years before Mingana's death. All the letters are written in Arabic. The letters were written on sheets that were usually folded in half, so that each sheet consisted of four pages to write on. Some letters consist of multiple sheets and sometimes only half a sheet is inserted. In other cases Mattai used a full sheet without folding it in half.

Mattai's handwriting is identifiable as ruq'a, which is an Arabic script that was probably developed during the second half of the eighteenth century in the Ottoman chancery. ${ }^{21} \mathrm{Ruq}^{\prime} a$ is nowadays the most popular script for handwriting, especially in the Middle East (though not in North Africa). The fact that Mattai used $r u q^{c} a$ for his correspondence is not surprising, as the script had become standard for correspondence throughout the Arab lands of the Ottoman Empire after first being used in the Turkish-speaking Ottoman government. ${ }^{22}$ This tells us that Mattai was able to use the standard script in the same way as his Muslim contemporaries. This is interesting in light of his biography by Nematallah Denno.

The use of ruq'a is usually accompanied with the application of many ligatures. Because the script is utilized for daily tasks, it is often written quickly and with absence of many diacritical dots. Adam Gacek writes that ruq'a is never written with the auxiliary signs used to denote vowels in Arabic. ${ }^{23}$

21 Arabic has a number of different scripts, the most common are naskh, nasta lìq, maghribi and ruq'a. Printed Arabic script is usually an adaptation of naskh. Adam Gacek, "Ruq'a," in Encyclopedia of Arabic Language and Linguistics, ed. Kees Versteegh et al. (Leiden: Brill, 2008), 4:98-100.

22 Ibid.

23 Ibid. The Arabic script has some characters that are only distinguishable from each other by diacritical dots. The dots are a relatively late invention and while they are considered obligatory, at least in printed texts, they are often omitted in manuscripts and other handwritten material. In addition, there are auxiliary signs to indicate the short vowels, the absence of a vowel (sukūn), gemination (shadda), and the glottal stop (hamza). These are normally not written but are used in places to overcome ambiguity. 
While the letters are generally written in Arabic, a considerable number of them contain text in Classical Syriac. The Syriac text is written, as one would expect, using the serțō script of West Syriac Christians, of which Mattai's Syriac Orthodox Church is part. Syriac script is mainly used to list titles of Syriac texts and books that Mattai could provide to Mingana. The main text is never in Syriac.

A detailed examination of one of the letters reveals some interesting aspects of Mattai's use of both languages. Below is the letter sent by Mattai to Mingana on 4 October 1926 and the first letter in the collection - at that time Mingana was living in Manchester. A photograph of the letter is given and the beginning is transcribed and translated below:

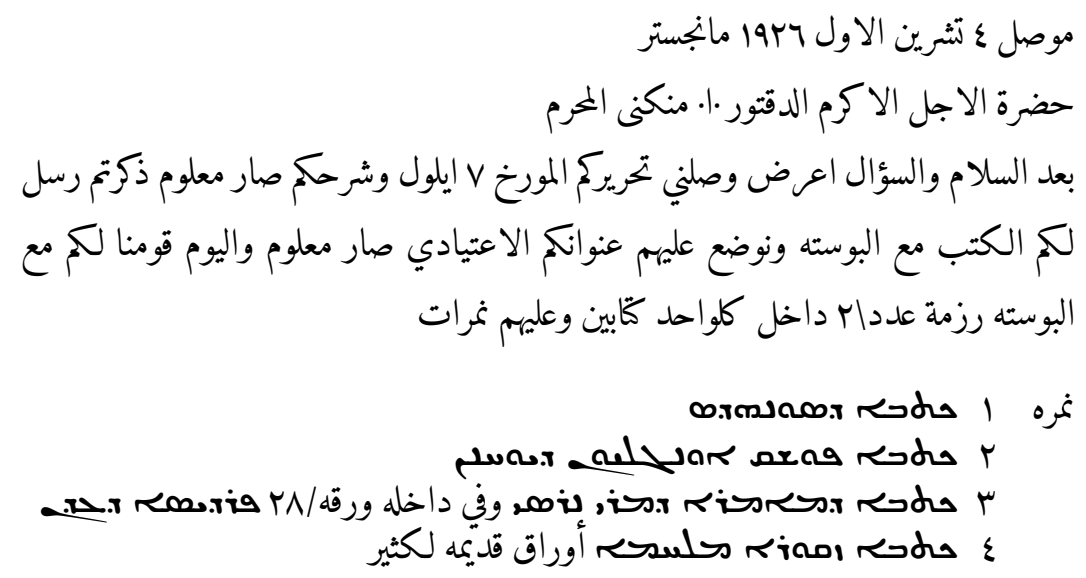

Mosul, 4 October 1926, (to) Manchester

The great and noble Doctor A. Mingana, the reverend

After a salutation and inquiry [of your well-being] we present [our letter]. I received your writing dated 7 August, and we understood your explanation. You mentioned [that you would like for us to] send the books to you by mail, and we [will] put on them your usual address, [the one] that we know. Today we arranged for you by mail two packages, each of which contains two books, carrying the numbers:

Number 1 Kthōbō d-sunhōdōs (Book of the synods)

2 Kthōbō Fūshōq ewangeliyōn d-Yuhanan (The book Commentary on the Gospel ofJohn)

3 Kthōbō d-mimrē $d$-Mōr Narsai (Book of homilies of Mar Narsai) and therein 28 leaves Fardaysō da-Den (Garden of Eden), very old leaves 
4 Kthōbō zqurō mlaḥmō (Book of good composition) ${ }^{24}$

The transcription above is as faithful to Mattai's handwriting as possible. Auxiliary signs have only been reproduced where they were present in the original text, and the same is true for the dots above the tä marbüt $a$ and under the alif maqșüra, which are often omitted in handwritten texts. Certain features are not visible, such as the way Mattai marks numbers with a line with a little hook underneath, in the usual practice. In some cases the noun to which the number belongs is written under the number and the line, indicated in the transcription with a slash (/). The year at the top of the letter is indicated with a similar line, but the cipher indicating the thousand (1) is integrated in the line. Further note should be made of the fact that Mattai uses the western Christian era instead of the Seleucid era ("of the Greeks"), which was still in use.

Looking at the orthography, there are some peculiar features. The uppermost line of the letter tells us that it was sent to Manchester; this is written in Arabic as مانجستر Mānjastir, while the modern spelling is دانشستر is addressed as a doctor, for which Mattai uses the word دقتور duqtür instead of duktür. These deviations from the usual practice can be explained by the age of the letters and the fact that these words were less well established than they are nowadays.

Mattai was quite consistent in writing all the diacritical dots that are necessary to distinquish a number of Arabic characters, but he often leaves out the two dots above the $t \bar{a}$ marbūta and of the final $y \bar{a}^{\prime}$, for which no regularity can be found. While vowel signs were not used in this letter, a few other letters do have them on a some words. The latter fact is contrary to Gacek's statement that ruq'a is never written with auxiliary signs (see above), and this demonstrates that Mattai employed a special kind of ruq'a.

The most interesting aspect of these letters is Mattai's use of Arabic. We have seen that Mattai uses a script that was the most common among contemporary Muslims in the eastern part of the Ottoman Empire. While it can be said that the use of auxiliary signs, even sparingly, is not common practice with this script, it is clear that Mattai used them in a professional way. The orthography shows some peculiarities, but these relate to European words that were not commonly used when Mattai wrote his letters. By looking at the syntax and other grammatical aspects, we find that even this small piece of writing stimulates discussion of a number of issues.

24 All cited letters are to be found in the Cadbury Research Library, Birmingham, DA66/3, unless otherwise indicated. 
In both Classical and Modern Standard Arabic grammar, plural inanimate nouns are considered feminine singular grammatically. While their forms are the same as those of animate plural nouns, they behave as feminine singular nouns in terms of agreement. We see in Mattai's texts that he does not apply this rule: plural inanimate nouns are simply treated as plurals and the agreement is as such. Interestingly, Mattai is quite consistent in carrying out this "incorrect" agreement. The first instance is the word الكتب al-kutub (the books); a few words later he refers to writing عليه 'alayhim (upon them), which is the preposition 'alā with a masculine plural pronominal suffix. Standard Arabic grammar would require that one refer to them/the books using a feminine singular pronominal suffix, which would be عليه 'alayhā.

There are different possibilities as to the origin of these peculiar features of Mattai's Arabic. Classical Syriac was probably the language in which Mattai wrote the most, as the vast majority of the manuscripts he copied were texts in this language. This language does not have the same rules of agreement - these are a specific feature of Arabic. Another factor relates to colloquial Arabic: in this region it is very common to ignore the agreement rules of Standard Arabic, or to apply them only sometimes. Thus Mattai's practice could also reflect, in one way or another, the colloquial Arabic of the region of which Mattai was most probably a native speaker.

While the letter consists of three pages (the third page is on the left half of the backside of the leaf), Mattai's signature is visible in the lower left corner of the photograph, after which the text continues for a few lines. Under the signature we see Mattai's name in Arabic (الشماس متى بولوس al-shammās Mattā $B \bar{u}(\bar{u} s)$, and also his name in Latin characters, which can most probably be deciphered as "Matti Balis." In some other letters Mattai writes his name in Syriac as well, where it appears in various forms. In a letter dated 14 February 1928 he writes דrat Msham. Matay with a line above the first word, which is a common way of indicating an abbreviation in Syriac manuscripts. Another form is found in a letter dated 23 August 1927, where it is cola Mshamshōnō Matay Fawlōs.

The Mingana papers contain one letter from Mattai in English. This letter is not part of the large stack of letters in Arabic, but can be found in the main collection of Mingana's correspondence, which was held, for the most part, by European and American scholars. The English letter is one of condolence to Mingana's Norwegian wife, Emma Mingana, and was sent three months after Mingana's death. ${ }^{25}$ It is remarkable that Mattai wrote this letter in English in

25 University of Birmingham, Cadbury Research Library, DA66/1/5/6, dated 25 March 1938. 
light of the statement by Fiey that Mattai did not speak any foreign language. As Fiey met with Mattai several times, it does not seem probable that Fiey was wrong about this. Mattai must have had access to someone who could write this letter in English. There are numerous obvious mistakes, but apart from those, the English is remarkably good.

\section{Mattai's Biography by Nematallah Denno}

Mingana's archive in Birmingham, the Mingana papers, contains a very interesting document that is not written by Mattai, but that is about him. It is written by the Syriac Orthodox writer Nematallah Denno (1884-1951), ${ }^{26}$ who was a prominent writer for a periodical called Lisān al-mashriq (Tongue of the east, 1946-1951). ${ }^{27}$ The caption at the top of the document informs us that it is a tarjama (biography) of Mattai; indeed it contains a wealth of biographical information about him, although the nature of the laudatory text is such that one would almost be inclined to call the document a letter of recommendation.

It is not clear how this document became part of Mingana's archive. The document has a printed letterhead and is dated 21 November 1929, but does not carry the name of the addressee. Assuming that it was addressed to Mingana, it seems improbable that the document was meant to recommend Mattai to Mingana, as, at that time, they had already been cooperating for many years. It is possible that Mingana was in need of biographical information about Mattai for other reasons, but then the question remains why he did not ask Mattai himself for this information.

Like Mattai's letters, this document is written in Arabic, but the script is different than that of Mattai. While Mattai used a common Arabic script, Nematallah wrote this document in Syriac script. This practice, called Garshuni, used to be widespread for Syriac Christians in a variety of places. Just like later forms of Judeo-Arabic, the Arabic language was rendered in Syriac script by using one Syriac character for each character that would have been used for Arabic,

26 More information can be found in Rudolf Macuch, Geschichte der spät- und neusyrischen Literatur (Berlin: de Gruyter, 1976), 440-441. Just like Mattai, Nematallah's name has various forms and I prefer to use here the rendering in Latin characters that he used himself.

27 The periodical was at the beginning called al-Mashriq and carried also the Syriac title (Leshōnō d-)Madhnḥō. The periodical is exhibited in the Syriac Heritage Museum in Ankawa (Iraq), where Nematallah is mentioned in the description. Inquiry among local scholars made clear that Nematallah was well known, while Mattai was not. 
that is to say, the Arabic orthography was completely reproduced, it is only the graphemes that were different.

By examining this document, of which the top part is shown, some aspects of Nematallah's specific use of Garshuni emerge. In contrast to the text of the document itself, the printed letterhead is not in Garshuni: the part at the right is completely in Arabic, and the part at the left is in French, with the exception of the upper left part, which is in Syriac. The Arabic part has at the top a calligraphic version of Nematallah's name (نعمة الله دنو Nimat Allāh Dannū), followed by the name of the place (Mosul, Iraq) and the telegraph address, which is simply his name followed by the name of the city. The bottom part is the place and date, with the place (Mosul) and the first two ciphers of the year preprinted. Like the preprinted text, the date is completed using Arabic in Arabic script instead of Garshuni. The script type is again sophisticated ruq'a.

The first line of the left part of the printed letterhead is in Syriac. As "Nematallah" is an Arabic name, this part of the name is in Garshuni, while the part rendering "Denno" is different from its Arabic counterpart, written with two

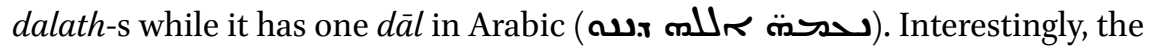
name of the place (Mosul, Iraq in Arabic) is given in Syriac as ow : indr STthur, Bayt Nahrin. While Bayt Nahrin means Mesopotamia and refers to Iraq, the word Öthur (Assyria) can indeed refer to the city of Mosul. Although the part on the left below the line in Syriac can be identified as French, the city of Mosul is spelled in the English way (instead of "Mossoul" in French), and Iraq has the odd spelling of "Irag" (French "Irak").

Below I illustrate the main body of the document again by transcribing and translating the beginning of it (lines 1-8). For the sake of Arabic readers, I transcribed the Garshuni into Arabic characters. Nematallah's handwriting is so clear that transcription is not necessary.

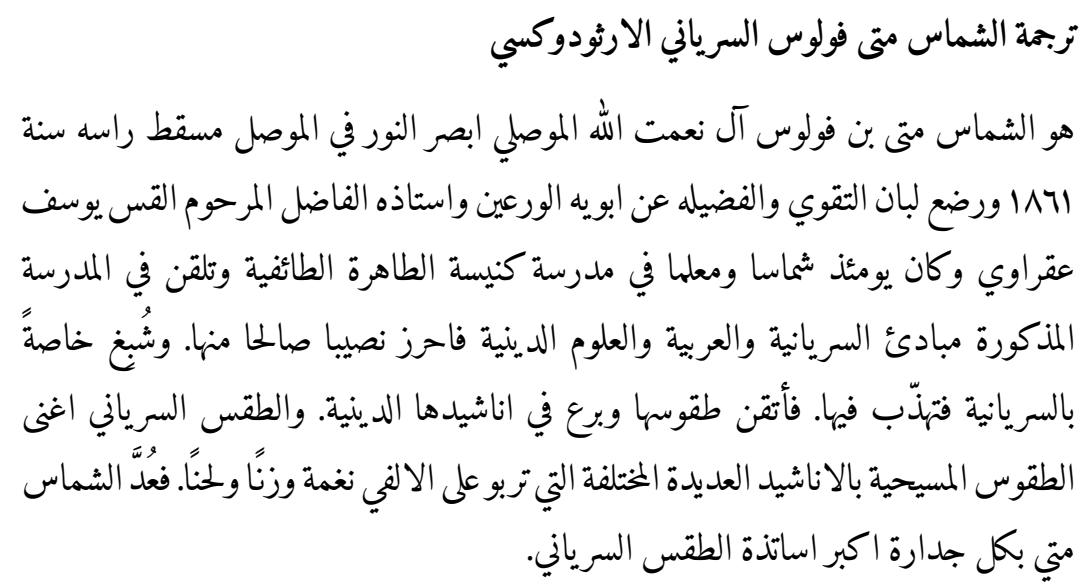




\section{Biography of the Deacon Mattai Paulus the Syriac Orthodox}

He is the deacon Mattai, son of Paulus, of the family of Ni'mat Allāh, of Mosul. He saw the light in Mosul, his place of birth, in the year 1861; he sucked milk of devotion and virtue from the fatherhood of piety, and his teacher was the late priest Joseph 'Aqrāwī-he was at the time deacon and teacher in the confessional school of the al-Ṭanhira church — and he learned at the mentioned school the foundations of Syriac and Arabic and the religious sciences, and he obtained his good fate through it. He loved especially the Syriac language, which was the language of instruction. He was proficient in its rituals and distinguished himself in its religious hymns. The Syrian liturgy is richer than the other Christian liturgies with numerous different hymns, exceeding two thousand songs, both with meter and melody. Therefore, Matthew the deacon is considered with all appropriateness the greatest master of the Syrian liturgy.

Not long ago George Kiraz finished a volume on Syriac orthography as part of a large project that aims to explain Syriac grammar in a comprehensive way; thus far, it contains the most complete description of the practice of Garshuni. Nematallah's use of Garshuni appears to comply to the body of Garshuni literature that Kiraz has taken into account. ${ }^{28}$ This still leaves a considerable amount of freedom for the user of Garshuni in terms of the way Arabic is rendered. Because the Syriac alphabet has only 22 characters and Arabic has 28, a few characters are left ambiguous. Garshuni solves this by adding diacritical dots, but this is not obligatory. In addition to that, Syriac has no $t \bar{a} ' m a r b \bar{t} t a$ and no alifmaqșüra, so that for these respectively a he and yodh have to be used. In the case of $t \bar{a}^{\prime}$ marbu $t a$ it is possible to mark it explicitly by adding two dots on top of a $h e$, as in the Arabic script, but this is not possible for the alifmaqșūra. ${ }^{29}$ Where the Arabic script can indicate short vowels, gemination, and the glottal stop, this is also possible in Garshuni, as exactly the same auxiliary signs are used (the vowel signs and sukūn, shadda, and hamza). Nematallah is relatively generous in adding diacritical dots and auxiliary signs; he even added them in some cases where no ambiguity would arise.

Below the end of the quotation above there is another bit of Syriac. Because it is in the same script, this is not immediately visible when looking at the

28 George Anton Kiraz, A Grammar of the Syriac Language: Orthography (Piscataway: Gorgias Press, 2012), 1:294-298.

29 This is not possible because the Syriac yodh that is used to render both Arabic $y \bar{a}$ ' and alif maqșūra never has dots, while in Arabic the alifmaqșūra is marked by the omission of the dots. 
document. I have transcribed it with Syriac characters where the Arabic part is in Arabic script (lines 13-14):

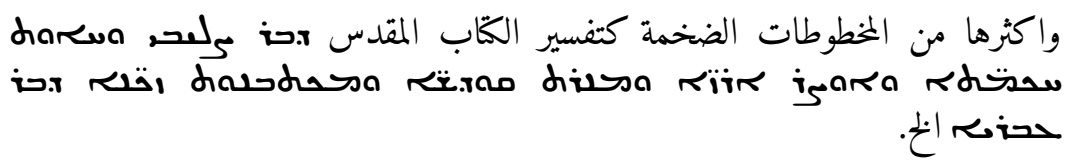

Most of them are from voluminous manuscripts such as the commentary of the Bible by Bar Șalibi, "Cream of Wisdom", "Storehouse of mysteries", "Candlestick of the Sanctuary" and the Chronicon by Bar Hebraeus, etcetera.

I have indicated the Syriac part of the quotation with italics. As in the letter by Mattai discussed above, Nematallah switches to Syriac to mention the titles of Syriac books. This is not surprising in itself, though he also uses Syriac for the words surrounding the titles and names of the authors. This is visible because of the Syriac word $d$ - (of, by), which does not exist in Arabic. The most curious phenomenon in this quotation is the part translated as "the commentary of the Bible by Bar Salibi." Nematallah renders the title of the book in Arabic, and then immediately switches to Syriac for the word $d$ - (of, by) and the name of the author. A couple of lines earlier (not quoted) he rendered the name in Arabic as ابن الصلبي Ibn al-Salbi (lines 9-10).

\section{Arabic, Syriac, and Garshuni in a Different Context: The Case of Inscriptions in Iraq}

In his catalog of inscriptions on Syriac Christian churches in Iraq, Amir Harrak discusses the languages that were used. Harrak's catalog comprises a wide time range, which shows very clearly certain trends through the centuries. As in the present case, the inscriptions are in Syriac, Arabic, and Garshuni. The oldest inscriptions are written in Classical Syriac only, but in the thirteenth century Arabic begins to appear, and its use increases continually over the following centuries. Garshuni comes into use in the seventeenth century_-before that all inscriptions in the Arabic language also use the Arabic script. From the nineteenth century, however, the use of Garshuni for inscriptions in Arabic starts to decrease, while Arabic in Arabic script continues to increase. Harrak mentions that there is no evidence for the use of Garshuni in inscriptions in the twentieth century, and Classical Syriac was only occasionally used in this time. ${ }^{30}$

30 Amir Harrak, Syriac and Garshuni Inscriptions of Iraq, Répertoire des inscriptions syriaques, part 1: Texts (Paris: Académie des inscriptions et belles-lettres, 2010), 42-43. 
The use of Garshuni in inscriptions displays two interesting features. First, many of the inscriptions are in colloquial Arabic rather than Standard Arabic. This was particularly true in the eighteenth century, while in the nineteenth century the Arabic in Garshuni started to "become more sophisticated"; this development is in line with the decline of Garshuni at the same time (the Arabic became standardized, both in language and in script). Second, most of the Garshuni inscriptions are translations from Syriac, and because of that the Arabic of the Garshuni inscriptions contain Syriac features to a great extent. ${ }^{31}$

In comparing the use of languages in inscriptions, a few observations are interesting to our case. First, as mentioned above, from the beginning of the twentieth century on Garshuni was not used for inscriptions, and this corresponds to the general trend of Garshuni dying out with the beginning of the nahda. Second, while in Harrak's inscriptions (before the twentieth century) Garshuni inscriptions appear in the colloquial Arabic of Mosul, our Garshuni writings use only Standard Arabic.

Harrak's data suggest a link between the standardization of Arabic and the disappearance of Garshuni beginning in the nineteenth century and concluding in the twentieth century. Our data seem to point in a different direction: Mattai's Arabic is in Arabic script while it is not completely standardized, and Nematallah used Garshuni, but his language follows the common rules. Before addressing the question of how this can be interpreted, I delve more deeply into the varieties of Arabic that we see in the documents.

\section{Middle Arabic, the Emergence of Modern Standard Arabic, and Garshuni in a Wider Perspective}

The phenomena we have seen concerning the language of the authors discussed thus far does not stand on its own and has been studied by others. Nevertheless, in the context of the early twentieth century the data are somewhat marginal, and existing research on Arabic provides less anchors to posit the material under consideration than one would normally have. In this respect, I discuss three issues: (1) Middle Arabic and the possibility of applying this term to Mattai's letters, (2) the emergence of Modern Standard Arabic, and the question: to what extent do our documents fall under it, and (3) the significance of Garshuni. Positing the material in the discussions concerning these three phenomena will not only help us to understand its significance for the way Mattai

31 Ibid. 
and Nematallah used languages in communication, but it will also show where the material can be used for the further study of the linguistic phenomena in a general sense.

In his introductory book on the Arabic language, Kees Versteegh gives a simple definition of Middle Arabic as "the collective name for all texts with deviations from Classical grammar,"32 but it is generally only applied to premodern texts that were presumably meant to be in Classical Arabic but which show a considerable number of deviations from the standard, many of which have their origin in colloquial Arabic. ${ }^{33}$ Had Mattai's letters been written a few centuries earlier, they would almost certainly be described as Middle Arabic because of the peculiar features I describe above, and with recent research in mind it is worthwhile to ask if perhaps the term ought to be applied to Mattai's texts.

The term Middle Arabic became especially well established after the studies by Joshua Blau, which are still almost always referred to when the phenomenon is discussed. ${ }^{34}$ But research on Middle Arabic has not stood still and a few developments are worth mentioning. In the introduction to a volume on Middle Arabic and Mixed Arabic that appeared after the third conference of the Association internationale pour l'étude du moyen arabe et des variétés mixtes de l' arabe, Johannes den Heijer gave a very useful description of recent developments that arose from the variety of conference contributions. ${ }^{35}$ One conclusion is that the definitions of Middle Arabic and Mixed Arabic (the latter term traditionally refers to spoken Arabic that does not fully comply with the standard, but is also not completely colloquial) should not be

32 Versteegh, The Arabic Language, 114.

33 The word "Middle" in Middle Arabic is ambiguous, as it can refer to a time period (between Classical and Modern Standard Arabic) and to the fact that the language of Middle Arabic is positioned between the standard and the colloquial. Most authors assume the latter meaning, even though Middle Arabic texts are usually considered to fall in the period between the peak of Classical Arabic and the emergence of Modern Standard Arabic, which makes the situation even more confusing.

34 See for instance Joshua Blau, A Handbook of Early Middle Arabic (Jerusalem: The Max Schloessinger Memorial Foundation, the Hebrew University of Jerusalem, 2002), which contains an outline of "Middle Arabic grammar" accompanied by a number of texts through which the reader can get acquainted with Middle Arabic texts and its peculiar features.

35 Johannes den Heijer, "Introduction: Middle and Mixed Arabic, a New Trend in Arabic Studies," in Liesbeth Zack and Arie Schippers (eds.), Middle Arabic and Mixed Arabic: Diachrony and Synchrony (Leiden: Brill, 2012), 1-25. 
limited to a certain period of time. In other words, while Middle Arabic usually refers to texts written between 800 and $1800,{ }^{36}$ and Mixed Arabic generally refers to modern spoken Arabic, this restriction is by no means necessary: the same framework that is used to analyze a medieval Middle Arabic text can be applied to analyze modern forum discussions on the Internet. ${ }^{37}$ The difference between Middle Arabic and Mixed Arabic is therefore only that the former term is used for written texts, and the latter for oral material. Indeed preliminary evidence shows that there are similarities in the phenomena in modern and medieval substandard texts, and only the use of a common framework can reveal that. ${ }^{38}$ This idea is rather new, as the research on Middle Arabic and Mixed Arabic only gained momentum during the last decade. More and detailed research on Middle (and Mixed) Arabic texts from the widest possible timespan is needed. ${ }^{39}$ No mention is made of texts that lie between the medieval and modern period, such as Mattai's, but they certainly fall under Den Heijer's definition.

A further important consideration is the question of whether it is possible that an author made a deliberate choice to write in Middle Arabic. Versteegh asserts that this is not the case, but Den Heijer questions this. ${ }^{40}$ Studying (written) Middle Arabic next to (spoken) Mixed Arabic is also useful in this sense, because it has been established that for spoken Arabic it is possible that one might deliberately use an intermediate form between the standard and the colloquial. ${ }^{41}$ Also in Mattai's case this question has to be asked.

Den Heijer's discussion makes it evident that texts like Mattai's could form a very important contribution to the study of Middle Arabic. Alone, they form too small a body of evidence to make more general assertions concerning postmedieval Middle Arabic, because we cannot yet determine to what extent Mattai's personal language represents a wider phenomenon. For our purposes the value of Den Heijer's discussion lies in the fact that it allows us to posit Mattai's Arabic as a form of Middle Arabic, even if it is neither the phase of Middle Arabic that was already firmly established (that of medieval texts) nor the one that appears in the conference volume to which Den Heijer wrote the introduction (on modern substandard texts).

\footnotetext{
36 See, for instance, Versteegh, The Arabic Language, 114.

37 Den Heijer, "Introduction," 10.

38 Ibid.

39 Ibid., 22-24.

40 Versteegh, The Arabic Language, 114, and Den Heijer, "Introduction," 10-12.

41 For instance in Versteegh, The Arabic Language, 191, where a proposed continuum of standard to colloquial spoken Arabic is cited.
} 
Seeing Mattai's Arabic as Middle Arabic is one thing, but if Mattai's intention was to write according to the standard, of which standard are we speaking? And what was the standard that Nematallah apparently applied? The second issue is therefore the emergence of Modern Standard Arabic and to what extent our writers were influenced by that.

The standard form of Arabic is generally referred to as lughat al-fuṣh $h$ ("the pure language"), regardless of what time period one is speaking about. Western scholarship normally makes a distinction between Classical Arabic and Modern Standard Arabic. There are good reasons for this, among them the obvious differences in vocabulary and grammar, especially syntax. A considerable volume of literature has been written on the emergence of Modern Standard Arabic, though this mainly deals with the necessity of creating new words for modern concepts, and the involvement of language academies in creating those. ${ }^{42}$ Discussions have also taken place about a grammatical reform of the language; in the end this had very little effect. ${ }^{43}$ This is not to say that there are few grammatical differences between Modern Standard Arabic and Classical Arabic. On the contrary, grammars have been written that deal explicitly with Modern Standard Arabic and provide ample evidence of significant differences, especially in terms of syntax and vocabulary. In this respect I mention the work by Badawi, Carter, and Gully, which, apart from giving a synchronical description, also compares modern forms with their classical counterparts. ${ }^{44}$

Unfortunately, apart from how new words have been added to Modern Standard Arabic, this research tells us very little about how Modern Standard Arabic came to be. We know the end result (Modern Standard Arabic), but we do not know how Modern Standard Arabic actually developed, that is to say, how the language changed over time in different contexts (places, religious communities, and individual authors). Because of this it is difficult to assess Mattai's ideal (taking for granted, again, that he was aiming for the standard) and Nematallah's Arabic with regard to whether we should see this as Modern Standard Arabic, or as a preliminary phase between Classical Arabic and Modern Standard Arabic.

\footnotetext{
42 See, for instance, Rached Hamzaoui, L'académie de langue arabe du Caire: histoire et oeuvre (Tunis: Université de Tunis, 1975).

43 Versteegh, The Arabic Language, 184-186. See the whole chapter (173-188) for a general overview of the emergence of Modern Standard Arabic.

44 Elsaid Badawi, M.G. Carter, and Adrian Gully, Modern Written Arabic: A Comprehensive Grammar (London: Routledge, 2003). As only written texts are used, the authors deploy the term Modern Written Arabic rather than Modern Standard Arabic.
} 
The third issue is the use of Garshuni and its significance. Various reasons for authors and scribes to write in Garshuni have been proposed, the most prominent of those being that it is a way to express Syriac identity. This is because Garshuni copies Arabic orthography and is therefore easy to learn for someone who knows the Arabic language and the Syriac script. ${ }^{45}$ It is an understandable solution for people who want to express themselves in the language they felt most comfortable with (in many cases Arabic, not Syriac) while at the same time expressing their Syriac identity through the script. But as we have seen, Nematallah's use of Garshuni is very late compared to the Garshuni in the inscriptions studied by Harrak, which cease in the nineteenth century. In a more general sense, Garshuni is considered to have been in decline as Arabic script increased from the beginning of the nahda. ${ }^{46}$

\section{Common Grounds: Arabic as the Best Solution}

The three issues described in the section above have one thing in common: they position the writings that form the basis of this paper in a preliminary phase between the premodern and the modern. As to the use of Middle Arabic (Mattai) and Garshuni (Nematallah), current literature suggests that the two writers were continuing traditions that might be considered anachronistic in the twentieth century. In this respect it is useful to take into consideration the beginning of the nahda, the period or movement of cultural revival (or "renaissance") in the Arab world.

The early history of the nahda is a controversial subject. Traditionally, scholars have considered it to have begun either with Napoleon's invasion in Egypt 1798 , or later, in the second half of the nineteenth century. Initially, western influence was seen as the main catalyst of the nahda-most obviously Napoleon's invasion, but also the influence of western missionaries that spread

45 F. del Río Sánchez, "El árabe karshūnī come preservación de la identidad siríaca," in P. Bádenas de la Peña (eds.), et al., Lenguas en contacto: el testimonio escrito (Madrid: Editorial CSIC, 2004), 185-194.

46 Alessandro Mengozzi, "The History of Garshuni as a Writing System: Evidence from the Rabbula Codex," in F.M. Fales and G.F. Grassi (eds.), Casemud 2007: Proceedings of the 13th Italian Meeting of Afro-Asiatic Linguistics, Held in Udine, May 21st-24th, 2007 (Padova: S.A.R.G.o.N. Editrice e Libreria, 2010), 300. For a recent and innovative history of the nahḍ, see Boutros Hallaq and Heidi Toelle (eds.), et al. Histoire de la littérature arabe moderne, part 1: 1800-1945 (Arles: Actes Sud, 2007). 
through the schools they established. More recent scholarship has tried to change this narrative by pointing to internal developments in the Middle East that started well before $1800 .{ }^{47}$

In a recent monograph, written to establish a new narrative drawing mainly upon Arabic sources, Abdulrazzak Patel devotes an entire chapter to one development that is very interesting in relation to our sources: "The Reintegration of Pre-modern Christians into the Mainstream of Arabic Literature." From approximately 1600 to 1800 , Christians once again became active participants in the Arabic literary realm, which they had been well-known participants of during the translation movement and through the thirteenth century. According to Patel, "[b]y the nahdah the reintegration of Christian writers into the mainstream of Arabic literature was complete and an inter-religious, almost suprareligious, space had evolved where Christian writers were no longer hampered by specific religious or theological considerations." 48 This process can therefore be seen as a "preparatory" internal development that opened the way for the nahda to begin full scale.

Other authors have noticed similar developments. In the course of the $n a h d a$, the language of literary production became more standardized, creating a link between the nahda and the emergence of Modern Standard Arabic, and new textual genres began to be deployed, such as novels and articles in journals. Christians took part in the nahda like Muslims, and already in the eighteenth century we can see that they adapted genres that had been deployed solely by Muslims. ${ }^{49}$ During the nahda Christians and Muslims began to use the Arabic language in the same sorts of ways; the tendency of Arab Christians to use Garshuni less is an explicit case of this. ${ }^{50}$

The documents presently under consideration show a picture that does not comply to this nahda hypothesis, as I will call this link between the nahda and the integration of the Christians' use of Arabic. Mattai writes in nonstandard Arabic, while Nematallah's Arabic, though it complies to the standard, is written in Garshuni, both practices associated with pre-nahda behavior. The fact that no Garshuni inscriptions are present in Iraq in the twentieth century, and the fact that the inscriptions in Arabic became more stan-

\footnotetext{
47 Abdulrazzak Patel, The Arab Nahda: The Making of the Intellectual and Humanist Movement (Edinburgh: Edinburgh University Press, 2013), in particular 4-5.

48 Ibid., 69.

49 Farouk Mardam-Bey and Hilary Kilpatrick, "L'état des lieux dans le monde arabe à la fin du XVIII siècle," in Hallaq and Toelle (eds.) Histoire de la littérature arabe moderne, 70 .

5o Mengozzi, "The History of Garshuni as a Writing System," 300.
} 
dard in the nineteenth century, reinforces the nahda hypothesis and therefore further distinguishes the practices of Mattai and Nematallah from the wider trend.

Our documents also bear witness to the use of the Classical Syriac language. While Mattai wrote a large number of manuscript colophons in Syriac (in addition to those he wrote in Garshuni), in his letters the Syriac is limited to the titles and the names of authors of books he could deliver, as well as his signature in some cases. This resembles the few examples of Syriac that we find in Nematallah's document, where we also find it used for book titles and authors, and as part of the trilingual printed letterhead.

Given that the two languages were used by both authors, the question is what reasons did they have to choose one or the other for these specific situations. Mattai was certainly able to write in Syriac, as Nematallah accounts for it and Mattai shows it through the colophons he authored. For Nematallah we do not have enough evidence from the documents, but we can speculate that he was likely also able to write in Syriac. Certainly they assumed that their intended readers (Mingana and possibly someone else) were able to read it. But writing a manuscript colophon is different than writing a letter: a colophon has a more or less fixed structure and uses a limited set of formulas. Writing a letter discussing modern-day problems (such as the cost of sending manuscripts by mail) is something for which a living writing tradition was needed, and while it is known that contemporary Syriac authors did write original texts in Syriac, we do not know if such a tradition was available to Mattai, and if so, if he was acquainted with it. The fact that Mattai even wrote some of his manuscript colophons in Garshuni suggests even more that he was not completely comfortable in composing Syriac. This leaves us with the possibility that they used Classical Syriac when it was needed (for book titles and authors) or for small symbolic pieces of text (Mattai's signature and Nematallah's printed letterhead).

The nahda hypothesis, discussed above, holds that during the period of the nahda Christians and Muslims used the Arabic language in similar ways and created a common standard in terms of language, script, and genres. In this way, the Arabic language in its standardized form created a very important new common ground between Christians and Muslims. Most of the evidence for this hypothesis, however, is based on material from Syria and Lebanon, mainly from Maronite, Greek Orthodox, and Catholic authors. This includes all of the authors that Patel discusses in his chapter on this topic. Mattai and Nematallah, based in Iraq, did not fully participate in this new common ground. While this can be seen as an argument against the nahda hypothesis, with the current evidence it is more likely an indication that the Mosul center of Syriac 
Christianity, at least with regard to its representatives Mattai and Nematallah, did not keep pace with Syria and Lebanon. Luizard's assertion that intellectual life in the city of Mosul lagged behind the rest of the Arab world, mentioned at the beginning of this paper, is in line with this hypothesis.

Mattai's and Nematallah's practice was nevertheless not an obstacle for their communication with Mingana, thanks to the fact that he was also of a Syriac Christian background, albeit from another denomination. By using Arabic in Arabic script in his letters, Mattai might have wished to put Mingana at ease, as he was (originally) an East Syriac Christian, not a user of Garshuni with West Syriac (serțō) characters. Nematallah did not feel constrained to use Garshuni, but we do not know the intended readership of his document. It can be said, therefore, that the communication between Mattai and Mingana forms another common ground-one common to Syriac Christians.

\section{Conclusion}

Mattai's letters to Mingana and Nematallah's biography show the use of a variety of languages and scripts. While this variety in itself is not surprising -it has always been a feature of Syriac Christian textual production-preferences for certain languages or scripts and ways of usage changed over time and differed according to place and denomination. The material addressed in this article shows that, by using non-standard Arabic, Garshuni, and occasionally Classical Syriac, Mattai and Nematallah deployed a style that was specific to Syriac Christianity. In comparison, contemporary writing of other Syriac Christians shows a move towards a common standard with Muslims and the use of Arabic; there is no indication that Mattai and Nematallah took part in this movement, or they did so to a lesser extent.

The post-nahda common ground of standardized Arabic, which I called the nahda hypothesis above, was not in use by everyone. Mattai and Nematallah are only one case. If other textual material from the early twentieth century written by Middle Eastern Syriac Christians and minorities in general becomes available, we will be able to map a more detailed view on the assumed common linguistic ground based on a standardized form of Arabic that began to form at the beginning of the nahda. At the same time, this will be of importance for the study of non-medieval Middle Arabic and the emergence of Modern Standard Arabic.

We have not heard the last word on Mattai bar Paulus. The large body of letters calls for comprehensive study, both to facilitate a linguistic analysis for the wider study of late Middle Arabic and/or early Modern Standard Arabic, and 
because of its relevance for Syriac Orthodox Christianity in early twentiethcentury Mosul. In addition, comparing the letters with the manuscripts in the Mingana collection might provide valuable information about the acquisition history and policy of Alphonse Mingana, which is still largely unknown. Publishing an edition of Mattai's letters is therefore a possibility that might be worth taking into consideration, as it would also shed light on this period of renewed use of Arabic among Syriac Christians.

\section{Bibliography}

Anonymous. Fahāris al-makhtūțāt al-suryāniyya fit-l-Irāq, two parts. Baghdad: Mațba'a al-Majma al-'Ilmī l-'Irāqī, 1977-1981.

Badawi, Elsaid, M.G. Carter, and Adrian Gully. Modern Written Arabic: A Comprehensive Grammar. London: Routledge, 2003.

Blau, Joshua. A Handbook of Early Middle Arabic. Jerusalem: The Max Schloessinger Memorial Foundation, the Hebrew University of Jerusalem, 2002.

Coakley, J.F. "A Catalogue of the Syriac Manuscripts in the John Rylands Library." Bulletin of the John Rylands Library 75, no. 2 (1993): 105-208.

Dāniyāl, Bihnām. Fahāris al-makhtūțāt al-suryāniyya fí Barțalla. Duhok: Dār al-Mashriq al-Thaqāfiyya, 2013.

Fiey, J.M. "Auteur et date de la chronique d'arbèles." L'orient syrien, revue trimestrielle d'Etudes et de Recherches sur les Eglises de langue syriaque, publiée avec la collaboration du Centre National de la Recherche Scientifique 12 (1967): 265-302.

—. Mossoul Chrétienne: Essai sur l'histoire, l'archéologie et l'état actuel des monuments chrétiens de la ville de Mossoul. Beirut: Imprimerie catholique, 1959.

Gacek, Adam. "Ruq'aa." In Kees Versteegh et al. (eds.), Encyclopedia of Arabic Language and Linguistics, 4:98-100. Leiden: Brill, 2008.

Hamzaoui, Rached. L'académie de langue arabe du Caire: histoire et oeuvre. Tunis: Université de Tunis, 1975.

Harrak, Amir. Syriac and Garshuni Inscriptions of Iraq, Répertoire des inscriptions syriaques, part 1: Texts. Paris: Académie des inscriptions et belles-lettres, 2010.

den Heijer, Johannes. "Introduction: Middle and Mixed Arabic, a New Trend in Arabic Studies." In Liesbeth Zack and Arie Schippers (eds.), Middle Arabic and Mixed Arabic: Diachrony and Synchrony, 1-25. Leiden: Brill, 2012.

Ignatius Aphram I Barsoum. The Scattered Pearls: A History of Syriac Literature and Sciences, translated and edited by Matti Moosa. Piscataway, NJ: Gorgias Press, 2003. Joseph, John. Muslim-Christian Relations and Inter-Christian Rivalries in the Middle East:The Case of the Jacobites in an Age of Transition. Albany: State University of New York Press, 1983 . 
Kiraz, George Anton. A Grammar of the Syriac Language: Orthography. Piscataway: Gorgias Press, 2012.

Luizard, Pierre-Jean. La formation de l'Irak contemporain: le rôle politique des ulémas chiites à la fin de la domination ottomane et au moment de la construction de l'Etat irakien. Paris: Editions du Centre national de la recherche scientifique, 1991.

Luke, Harry Charles. Mosul and its Minorities. London: Hopkinson, 1925.

Macuch, Rudolf. Geschichte der spät- und neusyrischen Literatur. Berlin: de Gruyter, 1976.

Mardam-Bey, Farouk, and Hilary Kilpatrick, "L'état des lieux dans le monde arabe à la fin du Xviıre siècle." In Boutros Hallaq and Heidi Toelle et al. (eds.), Histoire de la littérature arabe moderne, part 1: 1800-1945, 33-70. Arles: Actes Sud, 2007.

Mengozzi, Alessandro. "The History of Garshuni as a Writing System: Evidence from the Rabbula Codex." In F.M. Fales and G.F. Grassi (eds.), Casemud 2007: Proceedings of the 13th Italian Meeting of Afro-Asiatic Linguistics, Held in Udine, May 21st-24th, 2007, 297-304. Padova: S.A.R.G.o.N. Editrice e Libreria, 2010.

Mingana A. Catalogue of the Mingana Collection of Manuscripts, now in the Possession of the Trustees of the Woodbroke Settlement, Selly Oak, Birmingham, part I: Syriac and Garshūni Manuscripts. Cambridge: Heffer, 1933.

Patel, Abdulrazzak. The Arab Nahda: The Making of the Intellectual and Humanist Movement. Edinburgh: Edinburgh University Press, 2013.

Río Sánchez, F. del. "El árabe karshūnī come preservación de la identidad siríaca." In P. Bádenas de la Peña et al. (eds.), Lenguas en contacto: el testimonio escrito, 185-194. Madrid: Editorial csic, 2004.

Snouck Hurgronje, C. Abdoel-Ghaffaar: Sources for the History of Islamic Studies in the Western World, vol. 1: Orientalism and Islam: The Letters of C. Snouck Hurgronje to Th. Nöldeke from the Tübingen University Library. Published by P.Sj. van Koningsveld. Leiden: Documentatie bureau Islam-Christendom, Faculteit der Godgeleerdheid, 1985 .

Sūnī, Bihnām. Fahāris makhțūṭāt bĩat wālidat Allāh Maryam — al-țāhira fì BaghdēdāQaraqōsh. Duhok: Dār al-Mashriq al-Thaqāfiyya, 2010.

Versteegh, Kees. The Arabic Language. Edinburgh: Edinburgh University Press, 2001. 